\section{More global treaties}

SIR - Global environmental policies will be ineffective without international cooperation. As part of a study of multilateral environmental accords from 1920 to 1990 , we examined the record of multilateral treaty commitments by several large countries, looking at the total number of treaties legally joined by each and at whether the treaties: (1) constrained the domestic activities and sovereignty of the signatory; (2) addressed problems of global commons (as opposed to territorial problems); and (3) instituted regimes requiring active collaboration. We find important similarities (and differences) in treaty-making patterns, suggesting that norms and practices are shared to a greater extent than is commonly believed.

The top part of the table shows the treaty-making patterns of four 'advanced' countries, with a combined gross national product amounting to nearly 60 per cent of the global total. Perhaps because of its coastlines along both the North Sea and the Baltic, as well as its position in the centre of Europe, Germany participates in more environmental treaties (53) than the others, and shows the greatest tendency to accept constraints on domestic activities (33 treaties, or 62 per cent). More surprising is the extensive participation of the former Soviet Union, which has signed more treaties than the United States and Japan, and has accepted domestic sovereignty constraints in half of them.

The main industrial countries were rather uniform in their participation in commons and collaboration treaties. The United States exhibits the highest percentage of each type, but only by a small margin. Japan participates in only 37 treaties, 16 (43 per cent) involving con- straints on domestic sovereignty. But these numbers may well change, given Japan's recent activism on environmental issues.

The bottom part of the table shows the treaty commitments of four large developing countries, with a combined population accounting for nearly 44 per cent of the global total. These countries show lower rates of participation than the main industrialized countries, but they are relatively uniform among themselves. Like the developed countries, these countries are almost identical in percentage of commitments that were commons and collaboration treaties. Indonesia participates in a smaller number of treaties (13) than the others in the group, but nearly 70 per cent involve domestic sovereignty. At the top of the group by a small margin, India joined 26 treaties, 65 per cent of which constrain domestic sovereignty.

Given China's status as the world's most populous country (and one of the fastestgrowing cconomies), its participation in environmental treaties is particularly important. China ratified 22 treaties, a notable increase from the 15 it had ratified only a few years ago. Although only 10 of these involve constraints on domestic activities, China's performance is nevertheless encouraging considering its attitudes on most issues in world politics.

Nazli Choucri

Jan Sundgren

Department of Political Science,

Massachusetts Institute

of Technology,

Cambridge, Massachusetts 02142, USA

Peter M. Haas

University of Massachusetts,

Amherst, Massachusetts 01003, USA

\begin{tabular}{|c|c|c|c|c|}
\hline \multicolumn{5}{|c|}{ PARTICIPATION IN MULTILATERAL ENVIRONMENTAL TREATIES } \\
\hline & United States & Japan & Germany & Soviet Unlon \\
\hline \multicolumn{5}{|l|}{ Sovereignty-constraint } \\
\hline Domestic & $18(42)$ & $16(43)$ & $33(62)$ & $24(50)$ \\
\hline Foreign & $25(58)$ & $21(57)$ & $20(38)$ & $24(50)$ \\
\hline \multicolumn{5}{|l|}{ Problem-type } \\
\hline Commons & $28(65)$ & $22(59)$ & $32(60)$ & $30(63)$ \\
\hline Territorial & $15(35)$ & $15(41)$ & $21(40)$ & $18(38)$ \\
\hline \multicolumn{5}{|l|}{ Regime-type } \\
\hline Common aversions & $16(37)$ & $16(43)$ & $22(42)$ & $19(40)$ \\
\hline Common interests & $27(63)$ & $21(57)$ & $31(58)$ & $29(60)$ \\
\hline Total treaties in force & 43 & 37 & 53 & 48 \\
\hline Variable & China & Brazil & Indla & Indonesia \\
\hline \multicolumn{5}{|l|}{ Sovereignty-constraint } \\
\hline Domestic & $10(45)$ & $14(58)$ & $17(65)$ & $9(69)$ \\
\hline Foreign & $12(55)$ & $10(42)$ & $9(35)$ & $4(31)$ \\
\hline \multicolumn{5}{|l|}{ Problem-type } \\
\hline Commons & $12(55)$ & $11(46)$ & $11(42)$ & $6(46)$ \\
\hline Territorial & $10(45)$ & $13(54)$ & $15(58)$ & $7(54)$ \\
\hline \multicolumn{5}{|l|}{ Regime-type } \\
\hline Common aversions & $11(50)$ & $12(50)$ & $14(54)$ & $6(46)$ \\
\hline Common interests & $11(50)$ & $12(50)$ & $12(46)$ & $7(54)$ \\
\hline Total treaties in force & 22 & 24 & 26 & 13 \\
\hline
\end{tabular}

Numbers in brackets, percentages for each variable. Types of treaty are defined in the text.

\section{Adrenocentenary}

SIR - Heilbron and Bynum omitted from this list of discoveries having their centenary in 1994 (Nature 364, 11-14; 1994) the discovery of adrenaline, which was discovered by George Oliver and Edward Schaefer, here at University College London, in the department of physiology and first reported on 10 March 1894 (Proc. Physiol. Soc. 8, 1; 1894; J. Physiol. 16: i-v; 1895 \& 17, ix-xiv; 1895).

The first hormone to be called a hormone was of course secretin, also a product of this department, but in retrospect I think all will agree that adrenaline, also a true internal secretion, can justifiably claim priority. It was the first to be assigned a chemical structure, although John J. Abel and R. de M. Taveau of Johns Hopkins University got it wrong at the first try (J. biol. Chem. 1, $1 ; 1905)$. It was also the first to be chemically synthesized.

The assignment of the structure of adrenaline is also notable as an early instance of scientific skulduggery. Somewhere along the line, the Parke Davis Company got in on the act. It sent Jokichi Takamine to Baltimore and, with the information he gathered, went on to solve the structure. The name Adrenaline became a registered trademark of the Parke Davis Company: hence the US use of the term epinephrine.

All interested Adrenocentenarians are invited to attend a celebratory symposium to be held at the Wellcome Trust (10 and 11 March). This has the support of the Wellcome Trust, the Biochemical Society, the British Heart Foundation and the Physiological Society. In the very best traditions, the Parke Davis Company, invited to redeem its sins, has declined to comment.

\section{B. D. Gomperts}

Department of Physiology,

University College London,

University Street,

London WC1E נرש, UK

\section{HIV and AIDS}

SIR - If the serious medical problems of haemophiliacs were due to a general protein contamination of factor VIII treatments, as previously prepared, then these problems would have been apparent long before the spread of HIV. There does not appear to have been such a high risk apparent in the general population before the HIV epidemic. Hence I infer that AIDS in haemophiliacs is much more consistent with the HIV theory than with a general contamination hypothesis as suggested elsewhere.

\section{David Aikman}

Horticulture Research International, Wellesbourne, Warwick CV35 9EF, UK 